\title{
Argumentation-Based Learning in Social Studies Teaching
}

\author{
Birol Bulut ${ }^{1}$, Turan Kaçar $^{2} \&$ İrfan Arıkan ${ }^{3}$ \\ ${ }^{1}$ Faculty of Education, University of Firat, Elazig, Turkey \\ ${ }^{2}$ Division of Education of Social Studies, University of Firat, Elazig, Turkey \\ ${ }^{3}$ Faculty of Education, University of Harran, Sanliurfa, Turkey \\ Correspondence: Turan Kaçar, Division of Education of Social Studies, University of Firat, Rectorate Campus- \\ 23119, Elazig, Turkey. E-mail: kacarturan21@gmail.com
}

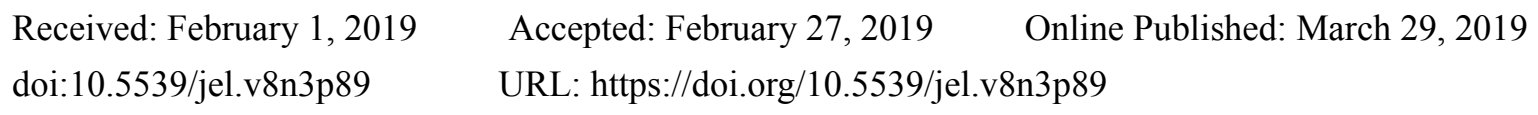

\begin{abstract}
An argument is the product that is produced as a result of the discussion to support a claim. Argumentation is a reasoning process in which arguments are generated by using claims, data and reasoning components. Argumentation-based learning is an effective approach that can be used to discuss ideas on sociological issues, and is particularly effective in teaching semi-structured problems, such as sociological issues. Social studies are the process of forming a bond based on proofs via social reality and getting dynamic information as a result. The aim of this study is to determine the place of argumentation-based learning in social studies teaching. Whether or not the argumentation-based learning approach is applied in social studies teaching constitutes the research problem. According to the data obtained from this study, it is thought that argumentation-based learning approach can be applied in social studies teaching. In this study, one of the qualitative research methods used in the document analysis method was used.
\end{abstract}

Keywords: argument, argumentation, argumentation-based learning, social studies

\section{Introduction}

According to Yaşar and Gültekin (2015), in the teaching-learning process, students' gaining the desired behaviors requires the use of appropriate strategies, methods and techniques and there are a number of strategies, methods and techniques to render effective teaching and learning, which will eventually facilitate the work of both students and teachers. To this end, students should be at the center of learning, students should be able to share their opinions and thoughts about the subjects easily in the classroom, only in such an environment can the student develop a positive attitude towards the lesson. The importance of active participation of students in this course can be better understood by taking into account that the social studies course is aimed at educating people who are constantly changing, understanding and working on the problems of the country and the world. While students are actively involved in the lesson, their application of argumentation-based learning approach is very important in terms of their decision-making skills, discussion skills, critical thinking skills and their development of science literacy.

There is the principle of scientificness among the Basic Principles of National Education that was set at code number 1739 in the Basic Rules of National Education of the Republic of Turkey. One of the approaches that may be appropriate for the development of science literacy skills in social studies course may be the Argumentation-Based Learning (ABL) approach. The great change and transformation in science and technology slow down the process of adaptation to society but The ABL approach will enable the individual to develop their decision-making processes, critical thinking skills, discussion skills, scientific and scientific literacy, thus enabling students to find solutions to the problems they face in life. The ABL approach can provide a working environment that allows the student to ask questions and provide evidence with evidence. The ABL approach is based on logical and scientific inferences. In this way, a new regulation can be brought to the logical inference.

The aim of this study is a theoretical study explaining that ABL approach is an appropriate approach to social studies course in social studies course. It is important to find the application area of ABL approach in the course of social studies course. The problem of the research is whether the ABL approach can be applied in social studies course. In the light of this problem, a literature study on argumentation-based learning was conducted in this study. 


\section{Method}

In this study, one of the qualitative research methods used in the document analysis method was used. The method of investigation is used to reach the resources for the purpose of the research and to determine the data to be obtained. Document analysis includes analysis of written and printed documents related to the subjects to be studied.

\section{Argument and Argumentation}

In the Turkish Language Association's Current Turkish Dictionary (2018), the argument means evidence, thesis, claim and argument. According to Kuhn and Udell (2003), the argument is the result of the discussion in support of a claim. According to the Güneş (2015), argumentation is trying to maintain or explain an idea, a hypothesis or a thought by using proofs. The proofs that are used in these explanations are arguments. Toulmin (2003) defines argumentation as a process of reasoning using arguments, data and reasoning components.

The components of the structure of the argumentation were determined by Toulmin (1958) as shown in Figure 1. (Küçük Demir, 2014).

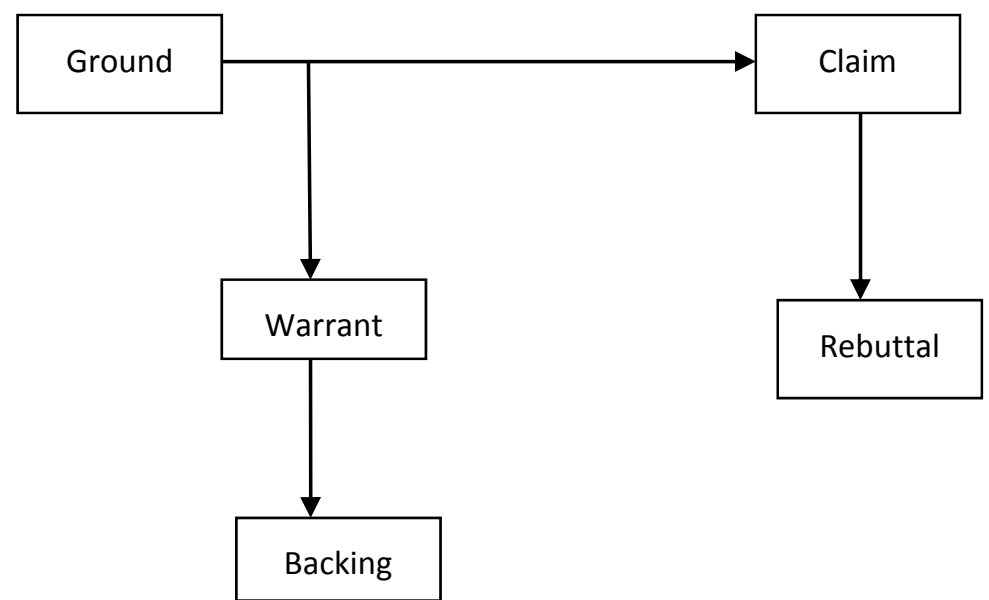

Figure 1. Argumentation model of toulmin

There are some theoretical and methodological drafts that define the method of argumentation. The argumentation model developed by Toulmin (1958) is the most inclusive of these drafts. This model forms the basis of the theoretical perspective of argumentation. According to the Toulmin argumentation model, the purpose of the discussion is to prove the claim. Discussion is based on data. Whether the reason is reliable or not is questioned with the supporter. In this model, it is stated that the qualifiers show the degree of reliability of the results from the arguments. Rejectors are statements made in order to refute allegations. All six components in the Toulmin argumentation model do not have to be in every discussion (Ayas, Çepni, \& Ayvac1, 2015).

The following examples (Ayas, Çepni, \& Ayvac1, 2015) are related to the argumentation model developed by Toulmin (1958).

Example 1:

Argument: Hakan's blood group is ARh + .

Data : Hakan's mother and father's blood group is ARh + .

Reason : The blood group of those whose mother and father have blood group ARh + usually becomes ARh + .

Supportive: According to the cross of Mendel, Hakan's blood group should be ARh +.

Modifier : Most likely.

Negatory : If the blood group of one of his family is not $\mathrm{ARh}+$, this claim becomes invalid.

Example 2:

Argument: The elm tree forests were annihilated in Turkey and the Middle Europe and a lot of species of trees are under threat.

Data : Acid rain has eliminated many plant species. 
Reason : A lot of trees destroyed elm forest species grown in Turkey and Central Europe are under threat.

Supportive: Increasing fossil fuels and decreasing forests increase the amount of carbon dioxide and threaten the lives of other living things.

\subsection{Argumentation-Based Learning}

According to Sadler and Donnely (2006), the ABL is an effective method for discussing sociological issues, where ideas are conveyed to students on the basis of evidence and it is particularly effective in teaching semi-structured problems such as sociological subjects. According to Leeman (1987), one of the teaching approaches that can make individuals think critically, question and use the scientific thinking method is the ABL approach which is the type of scientific discussion.

According to Dawson and Venville (2010), argumentation-based activities also have effects outside science education. It is expected in the democratic societies from the youth to have reasoning skills, capacity to think critically, develope both speaking and writing skills in a logical and consistent way. These features can be acquired with ABL approach. According to Zeidler and Nichols (2009), the use of the ABL approach in learning sociological subjects gives them experiences without ignoring the individual belief systems of students. According to Domaç (2011), ABL is important to be one of the methods of scientific discussion and not to accept any information that is not proven right.

According to Evagorou and Avraamidou (2008), argumentation provides the act of presenting evidence that is associated with a claim that is a cognitive feature, also improves the ability to assess the accuracy and validity of the argument. According to Melvillei, Yaxley and Wallace (2007), the other effective aspect of addressing sociological issues with the ABL approach is that it is effective in developing critical thinking skills, which is one of the gains of our changing education system.

\subsection{Social Studies and Argumentation-Based Learning}

According to Öztürk and Otluoğlu (2003), social sciences are composed of different disciplines within the social sciences and the approaches to teaching social studies have led to the emergence of many social studies definitions. In one of these definitions, Öztürk (2012) defined social studies as an interdisciplinary approach to social and skill sciences concepts in order to apply citizenship skills on critical social issues. In another definition, Sever (2015) stated that social studies were chosen from the disciplines of social sciences in order to educate citizens to make them good and responsible in primary schools, and based on information, students were given the skills, attitudes and values related to social life. In another definition, Sönmez (2010) defined social studies as the process of establishing a bond based on proving social reality and thus getting dynamic information as a result.

When the studies related to ABL were examined, it was seen that the studies related to ABL were mostly related to science education and there was not much work in the field of social studies education. Torun (2014) on the argumentation study examined the level of the relationship between argumentation-based teaching and decision-making skills in social studies. Torun (2014) found that the arguments produced by the students on the basis of argumentation have increased the level of arguments produced; the students produced higher quality arguments and a positive relationship between argument levels and decision-making skills. Based on these results, Torun (2014) gave more suggestions to the activities designed in accordance with the argumentation method in the social studies curriculum and textbooks, and in-service training of teachers for the use of this teaching, and suggested that teachers should prepare the environments in which students can incorporate them into the argumentation process.

Research shows that argumentation method has been used in science and mathematics for many years (Zohar \& Nemet, 2002; Duschl \& Osborne, 2002; Erduran, Simon, \& Osborne, 2004; Sadler \& Fowler, 2006; Kolsto, 2006; Albe, 2007; Chin \& Osborne, 2010; Kuhn, Wang, \& Li, 2010; Crowell \& Kuhn, 2012; as cited in Torun, 2014), and has been used in social sciences and humanities in recent years (Nussbaum, 2002; 2008; Larson, Britt, \& Kurby, 2009; Mirza \& Perret-Clermont, 2009; as cited in Torun, 2014).

Domaç (2011) aims to investigate the effect of argumentation-based activities on the academic success of pre-service teachers in terms of the importance of biodiversity and its importance in socio-scientific study. As a result of the results obtained from the study which was conducted with semi-experimental design without pre-test and post-test control group, a significant difference was found in favor of the last test. Therefore, it can be concluded that the ABL approach can be applied in social studies course due to the examination of socio-scientific issues in the ABL approach.

Soysal (2012) effect of the level of knowledge on the level of socio-scientific argumentation quality: in the study 
of genetically modified organisms in the context of the level of knowledge of the level of knowledge on the quality of socio-scientific argumentation in the context of genetically modified organisms. The sample of this study consisted of 71 teacher candidates. Data were collected by both quantitative and qualitative research techniques. According to the findings, it is concluded that the field knowledge is not an important factor in determining the quality of socio-scientific argumentation, and it is concluded that the level of knowledge of the candidate teachers towards genetically modified organisms is superficial.

Öztürk (2013) aims to develop argumentation skills and human rights attitudes of eighth grade secondary school students in an action research study on argumentation skills and development of attitudes towards human rights with socio-scientific issues. For this purpose, socio-scientific subjects in science and technology course were conducted with argumentation method. The data of the study, which consists of 26 secondary school students determined by criterion sampling method, were collected with argumentation skills and written documents on human rights, teacher and student diaries, camera records and attitude scale on human rights. According to the findings of the study, it was concluded that a positive attitude towards human rights was developed in the students as a result of the study conducted using the argumentation method, and that there was an increase in the quality of the arguments that the students created. Based on these explanations, it can be understood that the students' argument levels can be improved and the ABL approach can be applied in social studies course.

In their study, Oğuz and Demir (2016) concluded that the achievements of argumentation technique did not even constitute half of the social studies curriculum's total gains and they also found that the argumentation-based studies in social studies were insufficient. From this point of view, it can be thought that ABL has not been fully understood in the field of social studies education. According to Oğuz and Demir (2016), the argumentation technique is a system that facilitates the student to express himself/herself in addition, the student is using the data at hand, how to reach a conclusion, how to evaluate the criteria is a technique.

The social studies curriculum offers many opportunities for students to study and examine the discussion. The students can argue about the causes of historical events such as civil war, the desirability of social and political practices such as democracy or imperialism, or the current social issues such as death penalty or immigration. In a democracy, participation requires citizens to create convincing arguments. Therefore, a number of researchers have asked for more attention to the social studies curriculum aimed at improving students' ability to engage in discussion and logical discourse. (Barber, 1989; Wilen \& White 1991; as cited in Nussbaum, 2002).

Kırbağ Zengin, Keçeci, Kırılmazkaya and Şener (2011) in their study on ABL, students' awareness of nuclear power plants from socio-scientific issues increased, they realize that they have an important role in the decision-making process of social problems and students' sensitivity to their environment and critical thinking skills have increased. Furthermore, Kırbağ Zengin, Keçeci, Kırılmazkaya and Şener (2011) suggested that activities should be done to ensure that students are more sensitive to these social issues, and that the gains that provide awareness of responsibility towards their environment should be given more place in the course activities or textbooks. Therefore, the teaching of such socio-scientific subjects through the social studies course can provide more benefit to students.

\section{Results, Discussion and Sugestions}

When the literature studies on argumentation are examined, it is understood that most of these studies are in the field of science. In other disciplines, less work has been done, but in recent years it has been observed that studies on argumentation in the field of social studies education have increased. It is understood that the ABL approach can be applied in social studies course especially in socio-scientific subjects. It has been seen that the $\mathrm{ABL}$ approach is compatible with the social studies curriculum and textbooks. As a result, it is thought that $\mathrm{ABL}$ approach can improve students' decision-making levels, discussion skills and critical thinking skills in social studies course.

According to Melvillei, Yaxley and Wallace (2007), it is very effective to consider sociological issues with the ABL approach. According to Demirel (2015), argumentation practices in scientific and socio-scientific subjects are composed of applications based on the argumentation model of Toulmin. Based on these explanations, having scientific and socio-scientific subjects in social studies course may mean that ABL approach can be applied in this course.

Social studies course is a course that aims to educate individuals who produce knowledge, use them in life in a functional way, solve problems and think critically (MEB, 2018). The aim of this course is to teach students the subjects of society and individuals. In this course, students' subjective ideas about the subject are taken into consideration, but students are asked to approach events and facts with a scientific method. In this context, it is 
considered that it would be appropriate to use the $\mathrm{ABL}$ approach in providing a scientific perspective to students in social studies course.

The following offers are given based on the results obtained in this research:

1) As studies on social studies teaching for ABL are limited, the studies in this area should be increased.

2) Social studies teachers should be given seminars for ABL approach.

3) Activities based on ABL approach should be made in social studies course.

4) In social studies curriculum, argumentation-based gains should be more involved.

5) In particular, the argument levels of secondary school students should be improved further.

\section{References}

Ayas, A., Çepni, S., \& Ayvacı, H. Ş. (2015). Fen bilimleri derslerinde öğrencileri aktif kılan yöntem teknik ve modellemeler. In S. Çepni (Yay. haz.), Kuramdan Uygulamaya Fen ve Teknoloji Öğretimi içinde (12. Baskı). Ankara: Pegem Akademi Yayınları.

Dawson, V. M., \& Venville, G. (2010). Teaching strategies for developing students' argumentation skills about socioscientific issues in high school genetic. Reasearch in Science Education, 40, 133-148. https://doi.org/10.1007/s11165-008-9104-y

Demirel, R. (2015). Argümantasyon destekli öğretimin öğrencilerin kavramsal anlama ve tartı̧̧ma istekliliklerine etkisi. Kastamonu Ĕgitim Dergisi, 24(3), 1087-1108.

Domaç, G. G. (2011). Biyoloji eğitiminde toplumbilimsel konuların öğrenilmesinde argümantasyon tabanlı ögrenme sürecinin etkisi. Gazi Üniversitesi Eğitim Bilimleri Enstitüsü Yayımlanmamış Yüksek Lisans Tezi, Ankara.

Evagorou, M., \& Avraamidou, L. (2008). Technology in support of argument construction in school science. Educational Media International, 45(1), 33-45. https://doi.org/10.1080/09523980701847156

Güneş, H. (2015). Eğitim Bilimleri Terimleri Sözlü̆̆̈̈. Ankara: Ütopya Yayınları.

Kırbağ, Z. F., Keçeci, G., Kırılmazkaya, G., \& Şener, A. (2011). İlköğretim öğrencilerinin nükleer enerji sosyo-bilimsel konusunu online argümantasyon yöntemi ile ögrenmesi. Firat Üniversitesi 5. Uluslarars1 Bilgisayar ve Eğitim Teknolojileri Sempozyumu, Elazı̆g.

Kuhn, D., \& Udell, W. (2003). The development of argument skills. Child Development, 74(5), 1245-1260. https://doi.org/10.1111/1467-8624.00605

Küçük Demir, B. (2014). Argümantasyon tabanlı bilim öğrenme yaklaşımının öğrencilerin matematik başarılarına ve yaratıcı düşünme becerilerine etkisi. Ankara Üniversitesi Eğitim Bilimleri Enstitüsü Yayımlanmamış Doktora Tezi, Ankara.

Leeman, R. W. (1987). Taking Perspectives: Teaching Critical Thinking in the Argumentation Course. Annual Meeting of the Speech Communication Association, 73rd, Boston, MA, November 5-8, s. 24.

MEB, Talim Terbiye Kurulu Başkanlığı. (2018). Sosyal Bilgiler Dersi Öğretim Programı (İlkokul ve Ortaokul 4,5,6, ve 7. Sinıflar), Ankara.

Melvillei, W., Yaxley, B., \& Wallace, J. (2007). Virtues, teacher profrssional expertise, and socioscientfic issues. Canadian Journal of Environmental Education, 12, 95-109.

Nussbaum, E. M. (2002). Scaffolding argumentation in the social studies classroom. The Social Studies, 79-83. https://doi.org/10.1080/00377990209599887

Oğuz, S., \& Demir, F. B. (2016). Argümantasyon tekniğiyle sosyal bilgiler öğretimi. In R. Sever, M. Aydın \& E. Koçoğlu (Yay. haz.), Alternatif Yaklaşımlarla Sosyal Bilgiler Eğitimi içinde. Ankara: Pegem Akademi Yayınları.

Öztürk, A. (2013). Sosyo-bilimsel konularla argümantasyon becerisi ve insan haklarına karşı tutum geliştirmeye yönelik bir eylem araştırması. Çukurova Üniversitesi Sosyal Bilimler Enstitüsü Yayımlanmamış Doktora Tezi, Adana.

Öztürk, C. (2012). Sosyal bilgiler: amaç, içerik ve tarihçe. In C. Öztürk (Yay. haz.), Farklı Ülkelerin Sosyal Bilgiler Ögretim Programı içinde. Ankara: Pegem Akademi Yayıncılık.

Öztürk, C., \& Otluoğlu, R. (2003). Sosyal Bilgiler Öğretiminde Edebi Ürünler ve Yazılı Materyaller (2. Bask1). 
Ankara: Pegem Akademi Yayıncılık.

Sadler, T. D., \& Donelly, L. A. (2006). Socioscientific argumentation: the effects of content knowledge and morality. International Journal of Science Education, 28(12), 1463-1488. https://doi.org/10.1080/09500690600708717

Sever, R. (2015). Sosyal bilgilerin tarihçesi ve temel eğitimdeki yeri. In R. Sever (Yay. haz.), Sosyal Bilgiler Öğretimi içinde. Ankara: Nobel Yayıncılık.

Soysal, Y. (2012). Sosyobilimsel argümantasyon kalitesine alan bilgisi düzeyinin etkisi: genetiği değiştirilmiş organizmalar. Abant İzzet Baysal Üniversitesi Eğitim Bilimleri Enstitüsü Yayımlanmamış Yüksek Lisans Tezi, Bolu.

Sönmez, V. (2010). Sosyal Bilgiler Öğretimi. Ankara: Anı Yayıncılık.

Torun, F. (2014). Sosyal bilgiler dersinde argümantasyon temelli ögretim ve karar verme becerisi arasındaki ilişki düzeyi. Gazi Üniversitesi Eğitim Bilimleri Enstitüsü Yayımlanmamış Doktora Tezi, Ankara.

Toulmin, S. E. (2003). The Uses of Argument. London: Cambridge University Press. https://doi.org/10.1017/CBO9780511840005

Türk Dil Kurumu Güncel Türkçe Sözlüğü. (2018). Retrieved November 23, 2018, from http:/www.tdk.gov.tr/index.php?option=com_gts\&arama=gts\&guid=TDK.GTS.5bf7d57297f2e3.60317142

Yaşar, Ş., \& Gültekin, M. (2015). Anlamlı öğrenme için etkili öğretim stratejileri. In M. Safran (Yay. haz.), Sosyal Bilgiler Öğretimi Demokratik Vatandaşlık Ĕğitimi (4. Baskı) içinde. Ankara: Pegem Akademi Yayınları.

Zeidler, D. L., \& Nichols, B. H. (2009). Socioscientific issues: theory and practice. Journal of Elementary Science Education, 21(2), 49-58. https://doi.org/10.1007/BF03173684

\section{Copyrights}

Copyright for this article is retained by the author, with first publication rights granted to the journal.

This is an open-access article distributed under the terms and conditions of the Creative Commons Attribution license (http://creativecommons.org/licenses/by/4.0/). 